\title{
Analisis Aktor dalam Tata Kelola Usaha Mikro Kecil Menengah (UMKM) Kota Batu untuk Kualitas Internasional
}

\author{
Ruth Agnesia Sembiring ${ }^{1 *}$, Tia Subekti ${ }^{1}$
}

${ }^{1}$ Universitas Brawijaya, Indonesia

\author{
A R T I C L E I N F O \\ Article history: \\ Received 15 Desember 2020 \\ Accepted 21 Mei 2021 \\ Available online 30 Juni 2021

\section{Kata Kunci:} \\ Tata kelola; UMKM; \\ Kota Batu; Kualitas \\ Internasional \\ Keywords: \\ Governance; MSME; \\ Batu City; International \\ Quality
}

\begin{abstract}
A B S T R A K
Keberadaan Usaha Mikro Kecil dan Menengah (UMKM) di Indonesia bisa dibilang stagnan dan hanya mampu di pasar lokal. Kajian ini bertujuan untuk mengetahui bagaimana UMKM dikelola berdasarkan peran serta pola dalam kegiatan ekspor dengan konsep governance. Tata kelola UMKM memiliki visi untuk melibatkan aktoraktor: pemerintah, masyarakat dan sektor swasta. Dengan menggunakan studi kualitatif, kajian ini menggunakan data primer melalui wawancara mendalam kepada pihak Dinas Koperasi, Usaha Mikro dan Perdagangan (DISKUMDAG) Kota Batu, dan tiga UMKM pelaku ekspor di Kota Batu; serta dokumentasi media massa maupun tabloid yang memuat informasi mengenai ketiga UMKM yang menjadi fokus kajian. Pengumpulan data dilakukan dengan observasi terhadap lokasi dan kegiatan UMKM pelaku ekspor dan wawancara melalui pertemuan secara langsung maupun pertemuan secara tidak langsung terhadap narasumber. Kajian ini menganalisis aktor dalam tata kelola UMKM berkualitas internasional, pemasaran UMKM ke pasar internasional dan relasi antaraktor governance dalam rantai ekspor UMKM.
\end{abstract} Pemerintah memberi pelatihan dan pendampingan, menyelenggarakan pameran UMKM, dan program KITE. Pelaku UMKM sebagai bagian dari masyarakat memiliki tenaga kerja, memperoleh bahan baku, dan memiliki infrastruktur produksi. Pihak swasta membeli produk UMKM, memberi bantuan dana, memasarkan produk UMKM, dan mengirim produk UMKM keluar negeri. Governance model Liberal-democratic digunakan dalam tata kelola UMKM berbasis ekspor di Kota Batu, sehingga relasi pelaku UMKM dengan buyer dari luar negeri terjalin sebelum UMKM terbentuk dan terdaftar secara legal melalui dinas pemerintah. Dengan demikian, kajian ini menemukan bahwa pemerintah mengambil porsi sedikit dalam tata kelola UMKM berkualitas ekspor di Kota Batu. Kehadiran pemerintah dirasakan pada tahap perizininan dan pemenuhan syarat ekspor.

\section{A B S T R A C T}

Micro, Small, and Medium Enterprises (MSMEs) in Indonesia can be categorized as stagnant and can only develop at the local market level. This study aimed to determine how MSMEs are managed based on the role and patterns in export activities with governance. MSME governance has the vision to involve actors such as government, society, and the private sector. Through a qualitative study, this study uses primary data obtained through in-depth interviews with the Batu City Cooperative Micro-Business and Trade Agency (DISKUMDAG) and three MSMEs exporters in Batu City; as well as mass media documentation and tabloids which contain information about the three MSMEs that are the focus of the study. Data collection was carried out by observing exporters' MSME activities and interviews through direct meetings or indirect meetings with sources. This study analyzes actors in managing international quality MSMEs, the marketing of MSMEs to the international market, and the relationships between governance actors in the MSMEs export chain. The government, in this case, provides training and assistance, organizes MSMEs exhibitions and the KITE program. MSME actors as part of society have a workforce, obtain raw materials, and have production infrastructure. The private sector buys MSMEs products, provides funding assistance, markets MSMEs products, and sends MSMEs products abroad. The liberal-democratic governance model is used in export-based MSMEs governance in Batu City so that the relationship between MSME actors and buyers from abroad is established before MSMEs are formed and legally registered through government agencies. This study ultimately found that the government took a small portion in managing export-quality MSMEs in Batu City. The presence of the government is only at the licensing stage and fulfilling export requirements.

*Corresponding author.

E-mail addresses: nesi.biring@gmail.com 


\section{Pendahuluan}

Usaha Mikro, Kecil, dan Menengah (UMKM) Kota Batu hadir dalam sektor ekonomi untuk meningkatkan perekonomian masyarakat, yaitu tersedianya lapangan pekerjaan bagi masyarakat khususnya di tingkat lokal. UMKM di Kota Batu juga didukung potensi alam daerahnya yang merupakan daerah pegunungan. Pengenalan dan pemasaran produk-produk UMKM di pasar internasional tentunya menjanjikan keuntungan yang lebih daripada penjualan di pasar nasional. Untuk masuk di dalam pasar internasional, produk UMKM harus memiliki standar kualitas tertentu. Dalam rangka memenuhi standar kualitas ekspor, pelaku UMKM bukanlah aktor tunggal dalam tata kelola UMKM, mereka juga membutuhkan peran dari pemerintah dan swasta.

Kajian ini menggunakan konsep governance yang muncul di Indonesia sebagai salah satu bentuk pengembangan dari konsep yang mendahuluinya, yaitu government. Dari berbagai literature menjelaskan perbedaan sederhana dari kedua konsep tersebut yakni government merujuk pada pemerintah sebagai aktor tunggal dalam menjalankan pemerintahan. Sementara governance menekankan pada makna kepemerintahan yang mana melihat pemerintahan sebagai sebuah proses yang melibatkan berbagai aktor nonpemerintah dalam proses memerintah. Menurut Sumarto (2009), isu governance muncul sebagai dinamika dari adanya tuntutan perubahan dari masyarakat terhadap pemerintahan yang berjalan selama ini. Pemerintah dituntut untuk lebih demokratis, efisien, efektif, dan lebih tanggap serta mampu menyusun kebijakan yang menjamin hak asasi dan keadilan. Oleh karena itu, dalam mewujudkannya diperlukan kerjasama yang baik antaraktor, baik pemerintah maupun masyarakat. Governance diartikan sebagai mekanisme, praktik, dan tata cara pemerintah dan warga dalam mengatur sumber daya serta memecahkan masalah-masalah publik (Sumarto, 2009).

Definisi governance yang muncul dari berbagai ahli dan institusi dunia. Bank Dunia (1992, dalam Sumarto), mendefinisikan Governance sebagai "the manner in which power is exercised in the management of a country's social and economic resources for development." Asian Development Bank (1995), dalam papernya yang bertajuk Governance menyatakan bahwa Sound Development Management lebih menekankan pada empat elemen penting dalam good governance yaitu akuntabilitas, partisipasi, prediktibilitas, dan transparansi. Leach \& PercySmith (2001), governance meleburkan perbedaan antara pemerintah dan yang diperintah, kita semua adalah bagian dari proses governance.

Stoker (1998, dalam Sudarmo) menjelaskan adanya lima proposisi yang berkaitan dengan governance. Pertama, governance mangacu pada serangkaian institusi dan aktor yang berasal dari dalam pemerintah maupun dari luar pemerintah. Kedua, governance mengidentifikasikan kekaburan batas-batas dan tanggung jawab untuk menangani isu-isu ekonomi dan sosial. Ketiga, governance mengidentifikasikan ketergantungan kekuasaan yang terlibat dalam hubungan antara institusi yang terlibat dalam tindakan kolektif. Keempat, governance mengakui kepastian untuk mencapai sesuatu dengan tidak menggantungkan pada kekuasaan pemerintah untuk mengkomando atas menggunakan otoritasnya, governance memandang pemerintah mampu menggunakan alat-alat dan teknik-teknik baru untuk mengendalikan atau membina.

Sumarto (2009) melihat governance sebagai sebuah bentuk inklusifitas dalam proses pemerintahan yang mana jika government dipandang sebagai "mereka" maka governance adalah "kita." Dalam perkembangannya di Indonesia konsep governance kemudian dimaknai sebagai pelibatan berbagai stakeholder dalam tata kelola pemerintahan. Stakeholder yang dimaksud adalah state (negara atau pemerintah), private sector (sektor swasta atau dunia usaha), dan society (masyarakat sipil). Dalam mengelola pemerintahan, pemerintah tidak lagi menjadi aktor tunggal, namun memberikan kesempatan bagi aktor lain untuk turut serta dalam pemerintahan. Aktor swasta misalnya berperan dalam memberikan bantuan dana melalui kemitraan atau kerjasama CSR yang dimiliki oleh perusahaan. Sementara masyarakat 
berpartisipasi dalam memberikan masukan maupun mengawal segala bentuk program-program pemerintah.

Ada lima model governance menurut Pierre dan Peters (Pierre \& Peters, 2005). Pertama, model Etatiste yang menekankan pemerintah sebagai aktor utama dalam pemerintahan. Pemerintah berhak menentukan apakah ia akan memberi ijin atau tidak bagi masyarakat untuk turut campur dalam pemerintahan. (The assumption is that government is the principal actor for all aspects of governance and can control the manner in which the social actors are permitted to be involved, if they are at all). Kedua, model Liberal- democratic yang menerima pemerintah sebagai aktor utama dalam pemerintahan. Namun dalam model ini membebaskan aktor lain (misalnya: masyarakat) untuk berkompetisi dalam mempengaruhi pemerintahan. Selanjutnya, pemerintahlah yang berhak menentukan dan memilih aktor mana yang akan dilibatkan dalam pemerintahan. Ketiga, model State centric, di mana negara akan melembagakan hubungannya dengan swasta dan masyarakat melalui berbagai bentuk kemitraan. Seperti kemitraan dengan masyarakat sipil atau dengan korporasi. Keempat, model The Dutch governance school, dimana model ini bergantung pada jejaring sosial dalam pemerintahan. Dalam model ini memungkinkan posisi masyarakat lebih kuat mengingat kapasitasnya yang cukup besar dalam menghindari negara dan kebijakannya. Kelima, model Governance without government yang berpandangan bahwa pemerintah telah kehilangan kapasitasnya untuk memerintah sehingga lebih menekankan pada aktor swasta dan masyarakat yang berperan.

Pada praktiknya konsep governance digunakan dalam berbagai proses tata kelola pemerintahan seperti dalam pengelolaan ekonomi, masalah sosial, kesehatan, lingkungan, dan lain sebagainya. Dengan menggunakan konsep governance pula penulis akan melihat peran berbagai aktor yang terlibat dalam tata kelola UMKM untuk mewujudkan produk UMKM yang berstandar internasional. Aktor-aktor dalam governance tersebut idealnya mampu saling bersinergi dalam mendorong terwujudnya UMKM berstandar internasional.

Kajian ini bertujuan untuk membahas aktor-aktor dalam tata kelola UMKM Kota Batu agar produk dapat dijual ke pasar internasional. Konsep governance digunakan untuk menjelaskan bahwa tata kelola UMKM membutuhkan keterlibatan pemerintah, masyarakat khususnya pelaku UMKM, dan juga pihak swasta. Penulis juga menganalisis bagaimana model governance yang berlangsung pada tata kelola UMKM Kota Batu untuk meningkatkan standar produk ekspornya.

Kajian terkait dengan governance atau peran aktor dan UMKM telah ditelit oleh beberapa peneliti sebelumnya. Misalnya, penelitian yang dilakukan pada dalam melihat collaborative govarnance dalam pengembangan UMKM di era revolusi industri 4.0. Penelitian ini melihat bagiamana upaya kolaboratif antar aktor dalam pengembangan UMKM. Hasilnya kolaborasi antar aktor kurang berhasil dikarenakan tumpang tindihnya program dan kelompok sasaran (Faidati, 2019). Berikutnya penelitian lain juga menunjukkan bahwa peran antar aktor yaitu pemerintah, swasta, dan masyarakat dalam peningkatan UMKM di level lokal masih kurang maksimal. Sehingga berdampak pada rendahnya pengembangan potensi lokal pada UMKM (Agustina, dkk, 2014). Hubungan antara governance dan UMKM juga dilihat dari kajian Good Corporate Governance (GCG). Hasilnya tidak banyak UMKM yang memperhatikan penerapan GCG, mereka lebih pada upaya keberlangsungan usaha. Semakin besar ukuran UMKM (menengah-kecil) cenderung lebih banyak menerapkan indikator-idikator GCG daripada UMKM yang lebih kecil (Jaswandi, 2016). Sebagian besar penelitian yang berkaitan dengan governance dan UMKM adalah menyorot UMKM di level lokal. Belum banyak kajian yang melihat bagaimana peran aktor dalam governance yang melihat UMKM berskala ekspor. Padahal potensi UMKM berskala ekspor di Indonesia cukup besar, sehingga menarik untuk mengkaji dan analisis aktoraktor dalam governance atau tata kelola dalam perannya mengembangkan UMKM berskala internasional atau berskala ekspor.

Analisis aktor dalam tata kelola UMKM Kota Batu untuk kualitas internasional penting dilakukan sebab peran masing-masing aktor, yaitu Pemerintah Kota Batu, swasta, dan pelaku UMKM harus seimbang. Jika peran swasta dalam tata kelola UMKM terlalu besar dikhawatirkan dapat menciptakan eksploitasi. Eksploitasi terhadap pelaku UMKM dapat terjadi dalam hal kemandirian ketika menentukan keputusan pengelolaan UMKM, di mana pelaku UMKM 
cenderung mengikuti arahan dari pihak investor. Apabila hal ini terus berlanjut, dikhawatirkan para pelaku UMKM yang merupakan penduduk lokal seperti "pembantu" di rumahnya sendiri. Eksploitasi terhadap sumber daya alam lokal sebagai bahan baku produk dapat terjadi dalam upaya memenuhi permintaan pasar internasional, di mana sumber daya alam dieksploitasi tanpa mempertimbangkan dampak ekologis. Kehadiran pemerintah dalam tata kelola UMKM diperlukan sebagai aktor formal pembuat kebijakan untuk melindungi pelaku UMKM; untuk mengawasi pengelolaan sumber daya alam lokal agar tetap lestari, dan sebagai penghubung pelaku UMKM dengan pasar internasional. Namun kebijakan pemerintah dalam tata kelola UMKM melalui prosedur yang rumit juga dapat berdampak pada keengganan investor untuk melakukan penanaman modal dan keengganan pembeli dari luar negeri untuk melakukan pemesanan produk UMKM.

Sejauh ini Pemerintah Kota Batu telah menjalankan Peraturan Menteri Keuangan Nomor 177/PMK.04/2016 tentang Kemudahan Impor Tujuan Ekspor (KITE) IKM. Program KITE IKM ini dilaksanakan oleh Dinas Koperasi, Usaha Mikro dan Perdagangan (DISKUMDAG) Kota Batu. Program KITE IKM telah menghasilkan sejumlah kecil pelaku UMKM eksportir. Produk UMKM unggulan ekspor Kota Batu yaitu kerajinan mebel; hiasan peralatan rumah tangga dan ukiran kayu; gong (alat musik khas Jawa); kripik dan rempeyek (Sembiring \& Subekti, 2020). Dari sejumlah kecil UMKM unggulan ekspor Kota Batu, 3 (tiga) diantaranya adalah: CV Arjuna Flora, Arjuna 999, dan CV Delta Raya. Pelaku UMKM eksport tentunya masih membutuhkan upaya untuk mendorong para pelaku UMKM benar-benar layak menjadi eksportir, dan ini harus didukung Pemerintah Kota Batu dan swasta atau investor. Dengan demikian, dipandang penting meneliti lebih jauh mengenai analisis aktor dalam tata kelola UMKM Kota Batu untuk kualitas internasional.

\section{Metode}

Penelitian menggunakan jenis penelitian kualitatif. Penelitian kualitatif menurut Taylor \& Borgan (dalam Suyanto \& Sutinah, 2005), dapat diartikan sebagai penelitian yang menghasilkan data deskriptif mengenai kata-kata lisan maupun tertulis, dan tingkah aku yang dapat diamati dari orang-orang yang diteliti. Penelitian ini bertujuan untuk menganalisis lebih jauh tentang aktor-aktor pemerintah dan nonpemerintah dalam tata kelola UMKM berstandar internasional. Penelitian ini dilakukan di Kota Batu dengan fokus melihat peran pemerintah, sektor swasta, serta masyarakat khususnya pelaku UMKM dalam tata kelola UMKM berbasis ekspor.

Ada dua jenis data yang digunakan dalam penelitian ini. Data primer adalah data yang diperoleh langsung dari objek yang akan diteliti atau pun narasumber seperti dari pihak Dinas Koperasi Usaha Mikro dan Perdagangan (DISKUMDAG) Kota Batu dan pelaku eksportir dari UMKM Delta Raya, UMKM Arjuna Flora, dan UMKM Arjuna 999. Sedangkan data sekunder dalam penelitian ini didapatkan dari data penelitian sebelumnya, data dari dokumentasi media massa maupun tabloid yang memuat informasi mengenai UMKM Arjuna Flora, UMKM Arjuna 999, UMKM Delta Raya dan dokumen Dinas Koperasi Usaha Mikro dan Perdagangan Kota Batu.

Teknik pengumpulan data dilakukan melalui tiga teknik. Pertama, observasi untuk mendapat data secara rinci tentang kegiatan perilaku, tindakan orang-orang, serta juga keseluruhan kemungkinan interaksi interpersonal, dan proses penataan yang merupakan bagian dari pengalaman manusia yang dapat diamati (Suyanto \& Sutinah, 2005). Observasi yang dilakukan dengan pengamatan secara langsung pada objek penelitian yaitu UMKM di Kota Batu, khususnya UMKM Delta Raya. Kedua, wawancara untuk mendapatkan informasi dari narasumber. Seiring perkembangan teknologi, wawancara saat ini tidak harus dilakukan melalui pertemuan langsung, yaitu dengan memanfaatkan teknologi seperti panggilan telepon dan lain sebagainya. Penulis melakukan wawancara melalui pertemuan langsung terhadap pihak DISKUMDAG Kota Batu dan pelaku eksportir dari UMKM Delta Raya. Penulis juga melakukan wawancara melalui panggilan whatsapp terhadap pelaku eksportir dari UMKM Arjuna Flora dan UMKM Arjuna 999. Ketiga, dokumentasi yang dilakukan dengan mengumpulkan dokumendokumen dari DISKUMDAG Kota Batu, maupun dari data-data tertulis yang dimiliki oleh pelaku UMKM dalam penelitian ini. 
Analisis data dalam penelitian ini menggunakan model alir (flaw model) (Harrison, 2009) yang terdiri dari tiga tahapan. Pertama, tahap reduksi data, peneliti melakukan pemilahan dan pengelompokan data-data yang telah diperoleh dari wawancara narasumber, observasi dari lokasi UMKM Delta Raya maupun dokumentasi berdasarkan klasifikasi tertentu dari DISKUMDAG Kota Batu dan media massa atau pun tabloid yang memuat informasi mengenai tiga UMKM yang menjadi fokus penelitian. Kedua, peneliti melakukan penyajian data dan memberikan analisis berdasarkan konsep governance untuk menganalisis aktor dalam tata kelola UMKM berbasis ekspor di Kota Batu. Pada tahap ketiga, peneliti melakukan penarikan kesimpulan dan verifikasi berdasarkan data-data yang telah disajikan dan analisis masalah dengan menyajikan jawaban atas rumusan masalah yaitu bagaimana analisis aktor dalam tata kelola UMKM Kota Batu untuk kualitas internasional.

\section{Hasil dan pembahasan}

\section{Aktor gevernance dalam tata kelola umkm berbasis ekspor}

1) Pemerintah Pusat dan Pemerintah Kota Batu dalam Tata Kelola UMKM Berbasis Ekspor

UMKM di Kota Batu yang berhasil memasarkan produknya hingga pasar internasional boleh dibilang masih sedikit. Pemerintah Kota Batu melalui Dinas Koperasi, Usaha Mikro dan Perdagangan (DISKUMDAG) melakukan pelatihan dan pendampingan bagi pelaku UMKM mengenai pengelolaan pertanian dan perkebunan. Pelatihan dan pendampingan yang difasilitasi DISKUMDAG Kota Batu di Pusat Layanan Usaha Terpadu (PLUT) memiliki 5 (lima) kategori (Sembiring \& Subekti, 2020).

Pertama, pelatihan bidang makanan dilaksanakan dengan mendatangkan narasumber yang telah mumpuni dalam UMKM produk makanan. DISKUMDAG Kota Batu juga mengundang UMKM produk makanan untuk ikut dalam pelatihan pengembangan produk yang diselenggarakan oleh Pemerintah Provinsi Jawa Timur di Pelatihan, Pembinaan, dan Promosi Ekspor (P3E) Kota Surabaya. Agar pelaku UMKM bersedia menghadiri undangan ke P3E, DISKUMDAG Kota Batu memfasilitasi biaya transportasi, konsumsi, penginapan, dan uang saku untuk 10 (sepuluh) peserta yang mewakili seluruh kecamatan di Kota Batu.

Kedua, pelatihan bidang minuman juga mendatangkan narasumber yang telah mumpuni dalam UMKM bidang minuman untuk memberi pengetahuan dalam mengolah minuman agar tetap segar dan higenis. Pemerintah Kota Batu juga memberi bantuan berupa mesin pemotong buah, mesin penggiling buah, dan mesin press sari buah untuk UMKM bidang makanan dan minuman. Ketiga, pelatihan pengemasan produk dilakukan 2 (dua) minggu sekali di PLUT secara berkelompok berdasarkan kategori masing-masing UMKM. Keempat, pendampingan dalam administrasi dan manajemen, khususnya untuk masalah permodalan, Pemerintah Kota Batu melalui DISKUMDAG telah menghubungkan pelaku UMKM berbasis ekspor kepada pihak perbankan seperti Bank Indonesia (BI) dan Bank Rakyat Indonesia (BRI) dengan bunga rendah 3\%. Kelima, pendampingan oleh Pemerintah Kota Batu melalui DISKUMDAG kepada UMKM kerajinan kayu berupa pemberian informasi mengenai suplier kayu dan pemberian bantuan berupa mesin pembentuk kayu, mesin penghalus kayu dan mesin pemotong kayu.

Untuk pelatihan dan pendampingan dari Pemerintah Kota Batu melalui DISKUMDAG masih perlu dikreasikan dengan ide-ide yang lebih inovatif agar tidak menimbulkan kejenuhan bagi pelaku UMKM. Sebagaimana yang disampaikan Arjuna 999 bahwa sejauh ini isi materi pelatihan yang diselenggarakan sering kali sama, sehingga terkesan kurang memperhatikan pengembangan UMKM berbasis ekspor di Kota Batu (Arjuna 999, 2020). Pemerintah Kota Batu yang lebih dekat relasinya dengan pelaku UMKM perlu lebih memperhatikan permasalahan dan merumuskan alternatif-alternatif dalam pengembangan UMKM berbasis ekspor di kotanya.

Selain pelatihan dan pendampingan untuk pelaku UMKM, Pemerintah Kota Batu bekerja sama dengan pemerintah pusat melalui Kementerian Perdagangan mengundang pelaku UMKM untuk ikut dalam pameran misi dagang yang mengundang buyer dari luar negeri (Sembiring \& Subekti, 2020). Sejauh ini produk UMKM Kota Batu yang diperkenalkan dalam pameran misi dagang adalah produk makanan, minuman, kerajinan kayu dan tanaman bunga. 
Hasil kajian ini menunjukkan bahwa peran pemerintah pusat lebih besar dalam menyenggarakan pameran untuk produk UMKM Indonesia secara umum dan Kota Batu secara khusus. Seperti melalui Kementerian Perdagangan yang didukung oleh pihak swasta dalam menyelenggarakan pameran Trade Expo Indonesia (TEI). Pameran ini mendatangkan buyers dari luar negeri. Dengan konsep B2B (Business to Business), melalui TEI para produsen dari sektor industri, pertambangan, pertanian hingga kerajinan dapat memperkenalkan produk kualitas ekspor mereka kepada buyer dan buyer dapat melihat produk yang ditawarkan produsen secara langsung (djpen.kemendag.go.id). Dalam hal ini, UMKM Kota Batu tergolong produsen sektor pertanian dan kerajinan mengingat sebagian besar produk UMKM berbasis ekspor mengandalkan hasil pertanian dan perkebunan.

Arjuna 999 sebagai salah satu UMKM berbasis ekspor di Kota Batu menyatakan bahwa peran pemerintah pusat lebih besar ketimbang Pemerintah Kota Batu dalam penyelenggaraan pameran produk UMKM. Menurut pelaku UMKM Arjuna 999, ia mencari informasi secara mandiri mengenai pameran seperti TEI di BSD Gading Serpong; maupun informasi pameran UMKM hasil kerja sama Kementerian Koperasi dan Usaha Kecil Menengah yang diselenggarakan di mall SMESCO Rumah UMKM di Jakarta (Arjuna 999, 2020). Adapun cara pendaftaran untuk produsen dalam TEI adalah melalui http://www.tradexpoindonesia.com dengan mengisi form keikutsertaan, mengikuti proses kurasi dan membayar kelengkapan administrasi (tradeexpoindonesia.com). Selain TEI, pemerintah pusat melalui Kamar Dagang Indonesia (KADIN) pernah bekerja sama dengan Kamar Dagang Brunei Darussalam dalam menyelenggarakan pameran di mall Gadong Brunei untuk produsen produk ekspor Indonesia, termasuk untuk pelaku UMKM berbasis ekspor (Arjuna 999, 2020).

Hal yang sama juga penulis temukan pada UMKM Arjuna Flora yang beberapa kali mengikuti pameran produk UMKM yang diselenggarakan pemerintah pusat melalui Kementerian Pertanian. Pameran tersebut diantaranya IFEX \& National Product Expo, Pameran dan Workshop BIMP-EAGA dan Workshop APO (Asia Productivity Organisation), Short Course Export Management and Global Trade in Horticulture yang dilaksanakan di berbagai negara (tabloidsinartani.com, 2020).

Pemerintah Kota Batu berperan dalam mendata UMKM berbasis ekspor dan menyampaikan informasi atau pun undangan pameran-pameran yang diselenggarakan oleh pemerintah pusat melalui kementerian-kementeriannya dan juga pemerintah provinsi kepada pelaku UMKM. Seperti yang diungkapkan oleh pelaku UMKM Arjuna 999 bahwa Pemerintah Kota Batu melalui UPT Pendidikan Pelatihan dan Promosi Ekspor (P3E) Dinas Perindustrian dan Perdagangan (DISPERINDAG) secara rutin mengundang Arjuna 999 dan pelaku UMKM lain untuk turut serta dalam pelatihan, pameran maupun seminar untuk meningkatkan kualitas produk (Arjuna 999, 2020). Akan tetapi, Pemerintah Kota Batu masih perlu memperbaiki layanan informasi terkait undangan pamaren, khususnya mengenai bagaimana kriteria dan pembiayaan untuk mengikuti kegiatan tersebut. Menurut pelaksana UMKM Delta Jaya, Pemerintah Kota Batu pernah mengajak ikut pamaren tetapi tidak menjelaskan apakah biaya ditanggung oleh pemerintah atau dibayar secara mandiri oleh pelaku UMKM (Delta Raya, 2020). Tidak dapat dipungkuri bahwa biaya untuk mengikuti suatu pameran menjadi pertimbangan bagi pelaku UMKM untuk ikut serta.

Pemerintah pusat melalui Direktorat Jenderal Bea dan Cukai Indonesia berdasarkan Peraturan Menteri Keuangan PMK RI No.110/PMK.04/2019 juga menggagas Program Kemudahan Impor Tujuan Ekspor (KITE) untuk memberi kemudahan terhadap Industri Kecil dan Menengah (IKM), termasuk UMKM. Program ini juga wajib dijalankan hingga pemerintah tingkat lokal. Kemudahan yang diberikan kepada pelaku UMKM berdasarkan PMK RI No.110/PKM.04/2019 diantaranya tidak memungut Pajak Pertambahan Nilai dan Pajak Penjualan terhadap pemasukan barang/bahan yang impor untuk diolah, dirakit atau dipasang pada barang lain untuk menjadi hasil produksi yang memiliki nilai tambah dan untuk menjadi produksi ekspor. Barang/bahan yang dimaksud adalah bahan baku, termasuk bahan penolong dan bahan pengemas. 
Dalam kajian ini, barang yang diimpor untuk mendukung hasil produksi UMKM berbasis impor adalah mesin, termasuk peralatan atau perkakas yang digunakan dalam proses produksi. Sedangkan bahan yang diimpor seperti bibit tanaman untuk mendukung hasil produksi UMKM bidang pertanian. Salah satu kriteria dan syarat agar suatu IKM mendapat fasilitas KITE sesuai Pasal 4 Ayat 1 PMK RI No.110/PMK.04/2019, yaitu telah memiliki kontrak penjualan ekspor dan badan usaha telah melakukan kegiatan ekspor paling singkat 2 (dua) tahun. Dalam penelitian ini, pemilik UMKM yang ingin mendapat fasilitas KITE harus mengajukan permohonan kepada Kantor Pabean yang mengawasi lokasi kegiatan usaha dan pemilik UMKM harus mengisi beberapa dokumen yang diperlukan.

Arjuna Flora merupakan salah satu contoh UMKM berbasis ekspor yang mendapat fasilitas KITE (Sembiring \& Subekti, 2020). Bibit umbi Sandersonia diimpor oleh Arjuna Flora dari Jepang, salah satunya perusahaan florikultura Sagami Jitsugyo Co Ltd untuk dikembangkan di Kota Batu, lalu diekspor kembali ke Jepang dalam bentuk bunga potong (Arjuna Flora, 2020). Indonesia yang hanya memiliki dua musim dinilai lebih menjanjikan untuk mendapat bunga Sandersonia setiap tahun daripada di Jepang, dimana penanaman Sandersonia tidak dapat dilakukan setiap tahun apalagi pada musim dingin. Dengan program KITE, pelaku UMKM dapat lebih mengembangkan kerja sama dengan pihak swasta seperti investor asing dan dapat memperluas pemasaran hasil produksi hingga pasar internasional karena telah mengantongi legalitas ekspor.

Pemerintah Kota Batu melalui DISKUMDAG membantu Direktorat Jenderal Bea dan Cukai Indonesia serta para pelaku UMKM berbasis ekspor dalam menyampaikan permohonan kepada Kantor Pabean untuk mendapat fasilitas KITE. Ada kriteria dan syarat yang harus dipenuhi oleh UMKM berbasis ekspor (Sembiring \& Subekti, 2020), yaitu: (1) mengajukan surat permohonan ijin usaha ke DISKUMDAG Kota Batu; (2) pengisian blanko data pendirian usaha yang disediakan oleh pihak DISKUMDAG Kota Batu; (3) pengecekan dokumen dari masing-masing pelaku UMKM oleh DISKUMDAG; (4) pengajuan dokumen UMKM kepada Perdagangan Internasional Provinsi Jawa Timur oleh DISKUMDAG; dan (5) produk UMKM diserahkan ke Kantor Pabean dan dilakukan pengecekan ulang (proses akhir), produk layak diekspor atau tidak diputuskan oleh pihak Kantor Pabean.

Dari hasil penjelasan mengenai Pemerintah Pusat dan Pemerintah Kota Batu dalam tata kelola UMKM berbasis ekspor di Kota Batu, dapat diketahui bahwa pemerintah pusat memainkan peran yang lebih besar daripada Pemerintah Kota Batu dalam upaya meningkatkan produk UMKM kualitas ekspor. Kendati demikian, pemerintah baik pusat dan pemerintah lokal bukanlah aktor tunggal. Pameran-pameran produk dari sektor pertanian dan kerajinan milik UMKM yang diselenggarakan oleh kementerian-kementerian tentunya hasil kerja sama dengan pihak swasta yaitu buyers asing. Demikian pula dengan pelatihan dan pendampingan pelaku UMKM dan program KITE, ini bekerja sama dengan narasumber UMKM yang telah mumpuni dalam pemasaran produk ekspor. Tata kelola UMKM berbasis ekspor di Kota Batu masih sejalan dengan konsep governance yang menuntut pemerintah lebih demokratis dengan tidak memposisikan diri sebagai aktor tunggal dalam tata kelola ekonomi rakyat seperti UMKM.

\section{2) Masyarakat (Pelaku UMKM) dalam Tata Kelola UMKM Berbasis Ekspor}

UMKM berbasis ekspor di Kota Batu memperkerjakan 10 (sepuluh) hingga 50 (lima puluh orang) dan sering kali ada penambahan karyawan jika permintaan produk meningkat. Hal ini membuka lapangan pekerjaan dan dapat membantu masyarakat sekitar dalam meningkatkan perekonomian. Seperti Arjuna 999 yang memperkerjakan ibu-ibu di sekitar tempat tinggalnya (Arjuna 999, 2020). Arjuna 999 memiliki 13 (tiga belas) karyawan tetap. Namun jika permintaan terhadap produk meningkat, maka jumlah pegawai ditambah menjadi 30 (tiga puluh) karyawan. Karyawan tersebut dibagi menjadi beberapa fokus, yaitu fokus pada pemasaran, fokus pada pengemasan, fokus pada desain kemasaran, dan fokus pada pembuatan produk. Hal yang sama juga ditemukan pada Arjuna Flora yang memperkerjakan 30 (tiga puluh) hingga 50 (lima puluh) karyawan tergantung pada besarnya permintaan pasar pada produknya (Arjuna Flora, 2020). 
Selain karyawan, Arjuna Flora juga memiliki jejaring dengan kelompok tani agar dapat memenuhi permintaan produk hasil pertanian dari pasar internasional. Posisi Bu Luki, pemilik UMKM Arjuna Flora sekaligus sebagai Ketua Gabungan Kelompok Tani (Gapoktan) Mitra Arjuna sejak tahun 2007 (Arjuna Flora, 2020), ini menjadi peluang untuk membina para petani dalam meningkatkan produksi pertanian dan produk hasil olahan pertanian agar berkualitas ekspor. Gapoktan ini terdiri dari 200-an petani yang dibagi lagi menjadi kelompok komoditas sayurmayur, kelompok komoditas buah, dan kelompok komoditas bunga potong.

UMKM berbasis ekspor di Kota Batu mengandalkan hasil pertanian, perkebunan dan hasil hutan sebagai bahan dasar untuk mengolah hasil produknya. Untuk jenis UMKM bidang makanan dan minuman mengandalkan hasil pertanian seperti sayuran dan buah-buahan. Arjuna 999 yang merupakan UMKM bidang makanan mengandalkan hasil pertanian seperti kol, brokoli, sawi, cabai, tomat, nangka, apel, ubi ungu, pisang, rambutan, mangga untuk diolah menjadi keripik (Arjuna 999, 2020). Arjuna Flora juga mengandalkan hasil pertanian untuk diolah menjadi keripik buah dan sayur, namun UMKM ini lebih mengandalkan umbi bunga yang diimpor dari Jepang sebagaimana penjelasan pada sub bahasan sebelumnya (Arjuna Flora, 2020). UMKM Delta Raya mengandalkan hasil hutan seperti kayu pohon pinus dan rotan untuk diolah menjadi kerajinan kayu berupa ranjang tempat tidur, rak dan almari. UMKM ini melakukan analisis bahan baku yang dibutuhkan dan mengecek ketersediaan bahan baku lalu melakukan proses produksi (Delta Raya, 2020). Delta Raya mengambil bahan kayu dari pabrik karena sudah jelas legalitas dan surat-surat izinnya. Bahan baku sejauh ini didapat di wilayah Jawa Timur seperti pabrik kayu di Sidoarjo, rotan dari Gresik.

Pemenuhan standar kualitas ekspor untuk produk UMKM harus didukung tersedianya infrastruktur yang memadami. UMKM bidang makanan misalnya, membutuhkan infrastruktur berupa mesin vacuum frying yang diimpor dari negara asing. Buah dan sayur diolah menjadi keripik dengan mesin vacuum frying, yaitu sistem penggorengan hampa udara dengan suhu 70 derajat Celcus (Arjuna 999, 2020). Mesin ini menghisap kadar air dalam sayuran dan buah dengan kecepatan tinggi, sehingga nutrisi dalam sayur dan buah tetap terjaga. Vacuum frying juga tidak mengubah warna dan rasa pada sayuran dan buah. Untuk pengemasan keripik sayur dan buah, UMKM seperti Arjuna 999 menggunakan kemasan plastik berlapis aluminium floid dan diisi pula dengan nitrogen agar keripik tetap awet walau terkena sinar matahari.

Proses produksi untuk ekspor berbeda dengan proses produksi untuk pasar lokal. Menurut UMKM berbasis ekspor di Kota Batu, proses produksi tergantung pada permintaan buyers luar negeri. Arjuna 999 menyatakan bahwa jika ada permintaan sejumlah produk dari buyer luar negeri, maka UMKM ini akan memproduksi barang ekspor sesuai permintaan (Arjuna 999, 2020). Proses produksi bunga potong Sandersonia oleh Arjuna Flora juga tergantung pada permintaan buyer dari Jepang (Arjuna Flora, 2020). Demikian pula dengan UMKM Delta Raya, proses produksi untuk ekspor tergantung permintaan buyer asing, yaitu buyer asal Jepang yang memiliki kantor perwakilan di Surabaya (Delta Raya, 2020).

Dari penjelasan mengenai masyarakat (pelaku UMKM) dalam tata kelola UMKM berbasis ekspor, dapat diketahui bahwa pelaku UMKM dan masyarakat sekitar yang menjadi karyawan tidak dapat mengembangkan produknya tanpa melibatkan pihak swasta atau pun buyer dan juga pemerintah. Buyer tentunya memberi dampak pada jumlah permintaan dan mendorong pelaku UMKM untuk semakin meningkatkan kualitas dan kuantitas produk agar memenuhi standar ekspor.

\section{3) Pihak Swasta dalam Tata Kelola UMKM Berbasis Ekspor}

UMKM berbasis ekspor di Kota Batu mendapat bantuan pinjaman modal dari bank seperti Bank Rakyat Indonesia (BRI), Bank Indonesia (BI), dan Bank Negara Indonesia) dan Bank Jawa Timur (Bank Jatim). Walaupun bank-bank tersebut merupakan Badan Usaha Milik Negara (BUMN) dan Badan Usaha Milik Daerah (BUMD), penulis mengkategorikannya sebagai pihak swasta yang terlibat dalam penambah modal jika pelaku UMKM membutuhkan pinjaman modal. Arjuna Flora menyatakan bahwa Bank Indonesia telah merekomendasikan Arjuna Flora kepada BRI untuk mendapat bantuan modal (Arjuna Flora, 2020). Juga Arjuna 999 yang menyatakan 
bahwa BRI berencana memberikan pinjaman sebesar RP. 200.000.000.- (dua puluh juta rupiah) untuk pelaku UMKM di Kota Batu (Arjuna 999. 2020).

Kajian ini mengkategorikan buyer dari luar negeri sebagai pihak swasta yang ikut andil dalam tata kelola UMKM berbasis ekspor di Kota Batu. Tanpa permintaan dari buyer luar negeri tentunya produk UMKM tidak dapat dipasarkan keluar negeri. Pemilik UMKM juga harus dapat memenuhi permintaan yang disertai prosedur ekspor dan standar kualitas ekspor. Sejauh ini UMKM berbasis ekspor di Kota Batu diberi kebebasan dalam memilih buyer, asalkan memiliki legalitas dan memenuhi prosedur yang ditetapkan pemerintah. UMKM berbasis ekspor selalu mengutamakan pemasaran dan penjualan kepada buyer asing yang terlibat sejak UMKM dirintis. Sebagaimana Arjuna Flora dengan perusahaan florikultura asal Jepang, Arjuna 999 dengan buyer asal Hongkong, dan Delta Raya dengan buyer asal Jepang.

Dari penjelasan mengenai pihak swasta dalam tata kelola UMKM berbasis ekspor, dapat diketahui bahwa pemerintah pusat maupun Pemerintah Kota Batu telah memberikan referensi kepada pihak perbankan mengenai UMKM berbasis ekspor yang perlu mendapatkan bantuan dana. Dengan kata lain, pemerintah selalu melibatkan dirinya dalam tata kelola UMKM, khususnya dalam masalah pendanaan. Namun demikian, dalam tata kelola UMKM berbasis ekspor di Kota Batu perlu mengkaji kesigapan pemerintah dalam mengembangkan UMKM dan apa yang dilakukan pemerintah agar pelaku UMKM selalu merasakan kehadiran pemerintah dalam kegiatan usahanya.

\section{Pemasaran produk UMKM ke pasar internasional}

Berdasarkan hasil penelitian, terdapat tiga cara yang dilakukan oleh UMKM dalam melakukan produknya ke manca negara, yaitu melalui pemeran produk ekspor Indonesia, menggunakan platform digital, dan pemasaran produk langsung kepada buyer. Pertama, dari tiga UMKM yang diwawancarai hanya ada 2 UMKM yang pernah mengikuti pameran produk ekspor, yaitu UMKM Arjuna Flora dan UMKM Arjuna 999. Sementara menurut penuturan pelaksana UMKM Delta Raya, sejauh ini belum pernah mengikuti pameran. Delta Raya menuturkan bahwa sebelum pandemic Covid 19, DISKUMDAG Kota Batu pernah menyampaikan perihal rencana mengajak UMKM Delta Raya untuk mengikuti event pameran internasional di Dubai. Namun informasi tersebut belum ditindaklanjuti.

UMKM Arjuna 999 dan Arjuna Flora merupakan UMKM yang paling sering mengikuti ajang pameran produk UMKM yang diselenggarakan pemerintah pusat melalui kementeriankementeriannya. Sementara untuk pemerintah daerah sejauh ini belum pernah menyelenggarakan pameran bertaraf internasional untuk memfasilitasi pemasaran produk UMKM. Dari pengalaman Arjuna Flora dan Arjuna 999 menunjukkan bahwa keikutsertaan pada pameran internasional memberikan dampak positif bagi UMKM yang ingin melakukan ekpor. Pameran internasional menjadi media bertemunya UMKM dengan buyer dari luar negeri.

Kedua, pemasaran produk UMKM melalui platform digital merupakan peluang yang cukup besar di era digital saat ini. Menurut data Globalweb Index, pada tahun 2019 Indonesia merupakan salah satu negara dengan tingkat adopsi e-commerce tertinggi di dunia. Berdasarkan data tersebut, sebesar 90\% pengguna internet di Indonesia dengan rentang usia 16-64 tahun pernah melakukan pembelian produk atau jasa secara online (cnnindonesia.com, 2020). Ini menjadi salah satu peluang besar bagi pemasaran produk melalui e-commerce. Berikut beberapa daftar e-commerce di Indonesia dengan data jumlah junjungan pada tahun 2019 (inews.id, 2020): Tokopedia (1,2 miliar), Shopee (837 juta), Bukalapak (823 juta), Lazada (445 juta), Blibli (353 juta), JD ID (105 juta), Orami (89 juta), Bhinneka (63 juta), Sociolla (51 juta) dan Zalora (45 juta).

Namun demikian, adanya kondisi tersebut tidak memberikan dampak yang cukup signifikan bagi perkembangan pemasaran produk UMKM melalui e-commerce. Pengguna $e$ commerce di Indonesia masih didominasi oleh konsumen yang membeli produk dari dalam negeri maupun dari luar negeri. Sebaliknya penjual dari dalam negeri yang menjual barangnya ke ke luar negeri belum secara efektif dilakukan melalui e-commerce. UMKM berbasis ekspor di Batu sejauh ini menggunakan platform digitial untuk pemasaran produk melalui media sosial. 
Media sosial menjadi alternative pilihan pemasaran produk UMKM karena memiliki prosedur yang lebih mudah. Namun media sosial hanya terbatas pada pemasaran produk tidak sampai memfasilitasi penjualan secara sistemik. Penjualan tetap dilakukan secara manual, tidak tersistem dalam media sosial.

Arjuna 999 misalnya (Arjuna 999, 2020) menggunakan facebook sebagai market place online pada tahun 2011 untuk memasarkan rempeyek pada saat itu dan membuat produk rempeyeknya mendapat pesanan dari Hongkong. Arjuna 999 kemudian memperluas market place-nya melalui instagram dengan nama brand @momchips.official dan menyediakan link google drive berisi video dengan penjelasan dalam bahasa Inggris untuk membantu buyer asing mengenal produk keripik sayur dan buah milik Arjuna 999.

Berikutnya, Arjuna Flora yang menggunakan facebook dengan nama @Luki Budiarti, akun instagram @Luk_Budiarti, dan juga Tokopedia @ARJUNAFLORA untuk memasarkan produknya (Arjuna Flora, 2020). Arjuna Flora juga pernah mendapat tawaran dari Kementerian Perdagangan untuk bekerja sama dengan Alibaba untuk pemasaran produk keluar negeri. Namun Arjuna Flora lebih memilih pemasaran produknya melalui buyer asal Jepang yang sudah lama bekerja sama dengan Arjuna Flora. Sementara CV. Delta Raya sejauh ini belum menggunakan platform digital dalam pemasaran produknya.

Untuk mendukung adanya pemasaran produk UMKM melalui platform digital Pemerintah pusat sedikitnya telah melakukan dua langkah penting. Pertama, pada tahun 2019 Menteri Perdagangan mengeluarkan Peraturan Pemerintah Nomor 80 tahun 2019 tentang Perdagangan Melalui Sistem Elektronik (PMSE). Peraturan ini berisi tentang kepastian berusaha, equal playing field antarpelaku usaha, serta perlindungan konsumen yang diharapkan dapat menumbuhkan consumer trust dan consumer confident. Kedua, Kementerian Perdagangan (Kemendag) menandatangani perjanjian kerja sama dengan BukaLapak untuk menggaet 1.000 Usaha Kecil dan Menengah (UKM) mengekspor produknya ke 5 negara di Asia. Lima negara tersebut yakni Malaysia, Brunei Darussalam, Singapura, Hong Kong, dan Taiwan. Adapun produk-produk utama yang akan diekspor di antaranya pakaian khas Indonesia salah satunya batik, makanan dan minuman, kosmetik, produk berbahan dasar herbal, dan sebagainya.

Ketiga, pemasaran produk langsung kepada buyer adalah salah satu cara yang selama ini dilakukan oleh UMKM di Batu untuk masuk ke pasar ekspor. Pemasaran kepada buyer ini terjadi karena jaringan pertemanan yang dimiliki oleh pelaku UMKM dengan buyer dari luar. Seperti cerita dari pemilik UMKM Arjuna Flora yang mengawali kariernya di bidang pertanian dengan mengikuti kursus bahasa Jepang dan bahasa Inggris (Arjuna Flora, 2020). Pada saat kursus bahasa asing tersebut ia berkenalanan dengan seorang buyer dari Jepang yang menawarkan kerja sama dalam penanaman umbi bunga Sandersonia. Cerita yang sama juga dialami oleh UMKM Delta Raya. Awal mula bisa melakukan penjualan ke Jepang karena adanya jaringan pertemanan antara pemilik UMKM Delta Raya dengan buyer asal jepang yang berada di Surabaya. Dari jaringan pertemanan tersebut kemudian munculan transaksi jual beli hingga akhirnya rutin melakukan pemesanan (Delta Raya, 2020). Untuk UMKM Arjuna 999, permintaan buyer luar negeri muncul karena Tenaga Kerja Indonesia (TKI) yang ada di luar negeri. Buyer membeli rempeyek dari Arjuna 999 untuk dijual kepada TKI yang rindu makanan/cemilan khas Indonesia (Arjuna 999, 2020). Tingginya jumlah TKI di luar negeri menjadi peluang bagi UMKM makanan ringan khas Indonesia seperti Arjuna 999.

\section{Relasi antaraktor governance dalam rantai ekspor umkm}

Governance refers to the exercise of political and administrative authority at all levels to manage a country's affairs. It comprises the mechanisms, processes and institutions, through which citizens and groups articulate their interests, exercise their legal rights, meet their obligations and mediate their differences (un.org, 2012). Dari penjelasan tersebut menegaskan bahwa governance tidak terbatas pada peran masing-masing aktor, namun ini berkaitan dengan mekanisme, proses, dan pelembagaanya dimana kepentingan masyarakat diartikulasikan dengan baik. Dalam pemasaran UMKM konteks governance penting dilihat untuk melihat cara kerja masing-masing aktor dalam mendorong pemasaran UMKM berbasis ekspor. 
Peran pemerintah daerah yang masih minim menunjukkan bahwa pelembagaan UMKM berbasis ekspor melalui institusi negara masih belum dilakukan dengan baik. UMKM Delta Raya, Arjuna Flora maupun Arjuna 999 ketiganya sepakat bahwa peran pemerintah daerah masih minim. Ketiga UMKM tersebut sejauh ini mampu melakukan ekspor tanpa bantuan dari pemerintah daerah. Relasi antara aktor swasta (buyer luar negeri) dan masyarakat (pelaku UMKM) terjalin sebelum UMKM terbentuk dan terdaftar secara legal pada lembaga pemerintah.

Arjuna Flora digagas pada tahun 2001 oleh pemilik dengan buyer asal Jepang, kemudian UMKM ini legal berdiri pada tahun 2002 (Arjuna Flora, 2020). Arjuna 999 didaftarkan secara legal sebagai UMKM oleh pemilik ke DISKUMDAG Kota Batu setelah berita pengiriman produk rempeyek UMKM ini ke Hongkong dimuat pada harian Jawapos dan dibaca oleh walikota (Arjuna 999. 2020). Demikian pula UMKM Delta Raya yang secara legal berdiri karena pemiliknya memiliki relasi dengan buyer asal Jepang (Delta Raya, 2020).

Minimnya peran pemerintah daerah inilah yang menjadi salah satu faktor penghambat berkembangnya UMKM berbasis ekpor di level daerah. Keterlibatan pemerintah daerah yang minim dalam tata kelola UMKM berbasis ekspor, menurut penuturan Inol dari DISKUMDAG Kota Batu disebabkan permasalahan anggaran yang minim, seperti anggaran untuk menyelenggaran pameran produk UMKM. Berikut adalah relasi aktor governance pada rantai ekspor.

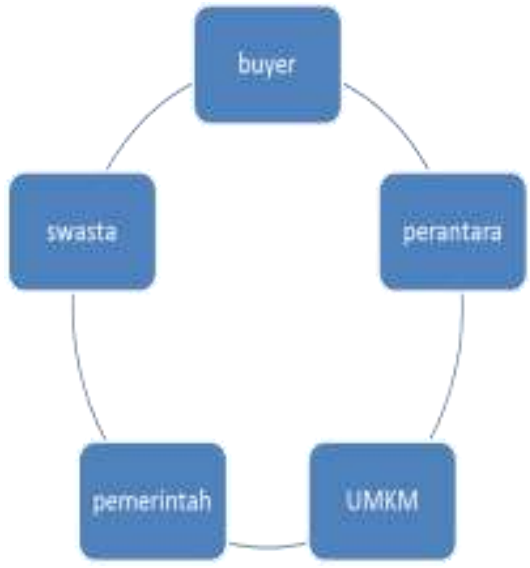

Gambar 1. Relasi Antaraktor pada Rantai Ekspor Produk UMKM Kota Batu

Sumber: hasil olahan peneliti, 2020.

Penjelasan rantai dimulai dari buyer/pembeli. Merujuk pada kasus 3 UMKM di Batu (Delta Raya, Arjuna Flora, Arjuna 999), buyer melalui beberapa perantara untuk bisa sampai di pembeli. Perantara tersebut tergantung pemasaran yang dilakukan oleh UMKM. Ada buyer yang membeli melalui online, melalui pameran, atau buyer yang membeli karena kenal langsung dengan pemilik UMKM. Setelah itu jumlah produk yang dihasilkan UMKM berdasarkan permintaan dari buyer. Pelaku UMKM akan membuat list order atau membuat Purchase Order (PO). Setelah menghasilkan produk, UMKM mengurus perijinan dan syarat administratif dari produk yang akan diekspor. Pada tahap perijinan dan syarat administratif inilah peran pemerintah mulai masuk.

Untuk UMKM bidang makanan dan minuman misalnya, setelah menghasilkan produk berdasarkan pesanan dari buyer harus didukung dengan pemenuhan standar internasional yang dikeluarkan oleh Lembaga Sertifikasi Sistem Hazard Analysis dan Critical Control Point (HACCP). Contohnya Arjuna 999 yang telah dan sedang mengerjakan renovasi untuk HACCP dan difasilitasi oleh Kementerian Koperasi (Arjuna 999, 2020). Contoh lain adalah UMKM bidang pertanian seperti Arjuna Flora dengan jumlah produksi umbi bunga Sandersonia dapat mencapai 80.000 juta per tahun. (Arjuna Flora, 2020). Umbi bunga Sandersonia harus lolos uji pada Perlindungan Varietas Tanaman dan Perizinan Pertanian (PVTPP), pengurusan Nomor Induk Kepabeaan (NIK) yang dikeluarkan oleh Bea Cukai, dan pada proses pengiriman keluar negeri umbi bunga Sandersonia juga harus melewati karantina dari Kementerian Pertanian. 
Demikian juga dengan UMKM bidang kerajinan kayu Delta Raya harus memenuhi syarat administratif seperti Invoice, Packing list, PEB (Pemberitahuan Eskpor Barang) dikeluarkan oleh Bea Cukai serta dokumen legalisasi kayu dari bahan baku yang dipakai (sertifikasi kayu) dari Kementrian Pertanian (Delta Raya, 2020).

Pengiriman barang kepada buyer dilakukan melalui shipping cargo. Untuk transaksi pembayaran salah satu caranya adalah pembayaran dengan model Letter of Credit/LoC. LOC merupakan cara pembayaran internasional yang menjadikan memungkinkan seorang eksportir menerima pembayaran langsung tanpa menunggu berita dari luar negeri. Pembayaran tersebut akan diterima setelah barang dan berkas dokumen dikirimkan ke luar negeri atau kepada pemesan (accurade.id, 2020). Melalui pembayaran model ini UMKM mendapatkan penangguhan biaya oleh bank. Cara ini menguntungkan baik buyer maupun UMKM. Model pembayaran ini memberikan keamanan dalam transaksi barang ekspor.

Berdasarkan penjelasan di atas berikut dapat dilihat bagaimana peran masing-masing aktor governance dalam tata kelola UMKM berbasis ekpor di Kota Batu seperti terlihat pada Tabel 1.

Tabel 1. Peran Masing-Masing Aktor Governance

\begin{tabular}{|l|l|}
\hline \multicolumn{1}{|c|}{ Aktor Governance } & \multicolumn{1}{c|}{ Peran } \\
\hline UMKM & Produksi barang \\
\hline Swasta (buyer) & Membeli barang \\
\hline $\begin{array}{l}\text { Swasta (e-commerce, bank, dan } \\
\text { jasa pengiriman barang) }\end{array}$ & $\begin{array}{l}\text { Pemasaran (platform digital, } \\
\text { promosi media sosial); } \\
\text { permodalan/pembayaran/transak } \\
\text { si; shipping atau pengiriman. }\end{array}$ \\
\hline Pemerintah & $\begin{array}{l}\text { Perizinan, administrasi, } \\
\text { pengecekan, pengawasan }\end{array}$ \\
\hline
\end{tabular}

Sumber: olahan peneliti, 2020.

Tata kelola UMKM berbasis ekspor nyatanya telah melibatkan semua aktor governance yaitu pemerintah, swasta, dan masyarakat. Ketiganya memiliki peran-peran masing-masing sesuai dengan porsinya dalam governance. Pemerintah memiliki peran yang lebih banyak dalam hal penentuan kebijakan dan syarat administratif yang sesuai dengan perundang-undangan. Swasta berfungsi sebagai buyer maupun sebagai fasilitator, baik untuk urusan perbankan dan juga pengiriman barang. Sementara masyarakat dalam hal ini pelaku UMKM merupakan aktor utama dalam tata kelola UMKM berbasis ekspor.

Berdasarkan lima model governance menurut Pierre dan Peters (Pierre \& Peters, 2005), tata kelola UMKM berbasis ekspor di Kota Batu tergolong governance model Liberal-democratic, dimana pemerintah melalui kementerian-kementeriannya sebagai aktor penentu dalam tercapainya penjualan produk UMKM ke luar negeri. Pemerintah mengesahkan kebijakan terkait penyediaan lembaga sertifikasi, lembaga perizinan, lembaga karantina maupun kemudahan impor barang/bahan untuk diolah menjadi produk ekspor. Pelaku UMKM wajib mematuhi prosedur-prosedur tersebut. Namun pemerintah juga memberi kebebasan kepada pelaku UMKM untuk berkompetisi seperti kebebasan untuk menjalin jejaring dengan kelompok tani, rekrutmen karyawan, memilih bahan baku hingga memilih buyer dari luar negeri. Sebagaimana menurut Arjuna Flora bahwa pemerintah pusat melalui kementerian-kementerian telah mempermudahnya dalam melengkapi persyaratan ekspor yang tidak memerlukan waktu berhari-hari (Arjuna Flora, 2020).

Tata kelola UMKM berbasis ekspor di Kota Batu juga memiliki hambatan, salah satunya kapasitas masyarakat sebagai pelaku UMKM yang masih rendah. Cara berfikir masyarakat yang masih belum peka terhadap peluang pasar ekspor. Hal ini disampaikan oleh pemilik UMKM Arjuna Flora yang pernah mendapatkan tawaran ekspor kentang namun terkendala dengan pasokan kentang dari para petani di Batu (Arjuna Flora, 2020). Ia menyampaikan bahwa 
keinginan untuk mengekspor kentang tersebut terkendala oleh mental para petani yang senantiasa mengharapkan keuntungan dalam waktu singkat tanpa prosedur ekspor yang mereka nilai menguras waktu dan energi dan para petani yang senantiasa mencari pembeli lokal dengan tawaran harga yang lebih tinggi.

Hambatan berikutnya adalah rendahnya kapasitas dalam pemenuhan bahan baku maupun permintaan barang dari ekspor. Kesulitan bahan baku misalnya dalam produksi makanan ringan yang membutuhkan bahan dasar berupa buah-buahan yang tumbuh secara musiman seperti rambutan dan mangga. Kesulitan bahan baku juga dirasakan pada UMKM Delta Raya terkait dengan pengadaan bahan baku berupa kayu yang harus menyesuaikan dengan spek barang yang dipesan oleh buyer. Sementara terkadang kayu yang dibutuhkan sulit didapat dan harus mengambil dari luar Pulau Jawa, sehingga kerap kali menghambat waktu produksi barang.

\section{Simpulan dan saran}

Tata kelola UMKM Kota Batu untuk meningkatkan kualitas ekspor melibatkan masyarakat (pelaku UMKM), pemerintah pusat dan pemerintah daerah dan juga pihak swasta dengan peran masing-masing. Pemerintah pusat dan pemerintah daerah berperan dalam pelatihan dan pendampingan pelaku UMKM, dalam penyelenggaraan pameran UMKM berkualitas ekspor, dan program KITE kepada pelaku UMKM. Masyarakat khususnya pelaku UMKM didukung oleh tenaga kerja, bahan baku, dan infrastruktur untuk melakukan proses produksi. Pihak swasta berperan dalam pembelian produk UMKM, pemberian dana, pemasaran, hingga pengiriman. Peran pemerintah pusat melalui kementerian-kementeriannya lebih besar daripada pemerintah daerah dalam tata kelola UMKM berbasis ekspor di Kota Batu. Penelitian ini menemukan bahwa relasi pelaku UMKM dengan buyer dari luar negeri terjalan sebelum UMKM terbentuk dan terdaftar secara legal pada DISKUMDAG Kota Batu. Ini menunjukkan ketidakhadiran pemerintah pusat dan pemerintah daerah pada awal UMKM dirintis untuk memenuhi permintaan pasar luar negeri. Peran pemerintah dirasa hadir ketika tahap perizininan dan pemenuhan syarat ekspor. Governance model Liberal-democratic digunakan dalam tata kelola UMKM berbasis ekspor di Kota Batu. Pelaku UMKM memiliki kebebasan untuk menjalin jejaring dengan kelompok tani, rekrutmen karyawan, memilih bahan baku hingga memilih buyer dari luar negeri. Namun, pemerintah melalui kementerian-kementeriannya dan kebijakannya sebagai aktor penentu dalam tercapainya penjualan produk UMKM ke luar negeri.

Pemasaran produk UMKM Kota Batu ke luar negeri dilakukan melalui tiga cara: melalui pameran produk ekspor Indonesia, menggunakan platform digital, pemasaran produk UMKM langsung kepada buyer. Hasil penelitian ini menemukan bahwa dari ketiga cara tersebut, penggunaan platform digital untuk pemasaran produk UMKM Kota Batu belum maksimal. Kontruksi platform digital seperti market place online dalam meningkatkan pemasaran produk UMKM keluar negeri nampaknya perlu mendapat perhatian oleh peneliti yang tertarik mengkaji pengembangan UMKM berkualitas internasional. Hal ini mengingat pemerintah Republik Indonesia telah memberikan izin kepada beberapa perusahaan market place online di Indonesia. Kehadiran perusahaan market place online di Indonesia harusnya membawa angin segar terhadap sektor ekonomi rakyat seperti UMKM di tingkat lokal.

\section{Ucapan Terima Kasih}

Terima kasih kepada Lembaga Penelitian dan Pengabdian kepada Masyarakat (LPPM) Universitas Brawijaya yang telah mendukung dan mendanai hasil penelitian ini, hingga dapat menghasilkan artikel karya ilmiah.

\section{Daftar Rujukan}

Accurate Indonesia, 30/04/2020, Letter of Credit: Pengertian, Fungsi, Jenis, dan Contohnya pada Bisnis, https://accurate.id/ekonomi-keuangan/pengertian-letter-of-credit.

Agustina, R. (2014). Peran Stakeholder Dalam Meningkatkan. Perekonomian Lokal Melalui Industri Kecil Menengah (IKM) (Studi pada Dinas Perindustrian, Perdagangan, Pertambangan dan Energi Kota Kediri). Jurnal Administrasi Publik (JAP), 5, 844-850. 
CNN Indonesia, 06/02/2020, Trend dan Peluang Industri E-Commerce di Indonesia 2020, https://www.cnnindonesia.com/teknologi/20200205204206-206-472064/tren-danpeluang-industri-e-commerce-di-indonesia-2020.

Faidati, N. \& Muthmainah, N. F. (2019). “Collaborative Governance Dalam Pengembangan UMKM di Era Revolusi Industri.” Webinar Konferensi Nasional Ilmu Administrasi (KNIA) Politeknik STIA LAN No.3, Vol.1 (2019).

Fiansah, R. (2020). 10 E-Commerce Terpopuler di Indonesia: Tokopedia Terdepan, Shopee Geser Bukalapak, https://www.inews.id/finance/bisnis/10-e-commerce-terpopuler-diindonesia-tokopedia-terdepan-shopee-geser-bukalapak.

Harrison, L. (2009). Metodologi Penelitian Politik. Jakarta: Kencana Prenada Media Group. Jaswadi. (2016). Analisis Tingkat Implementasi Good Corporate Governance Pada Usaha Kecil dan Menengah, Jurnal Siasat Bisnis Vol.20 No.2, 2016: 161-180.

Peraturan Menteri Keuangan PMK RI Nomor 110 / PMK.04 / 2019 tentang Perubahan Atas Peraturan Menteri Keuangan Nomor 177 / PMK.04 / 2016 tentang Pembebasan Bea Masuk dan Bebas Pajak Pertambahan Nilai atau Pajak Pertambahan Nilai dan Pajak Penjualan atas Barang Mewah atas Impor Barang dan / atau Bahan, dan / atau Mesin yang Dilakukan oleh Industri Kecil dan Menengah dengan Tujuan Ekspor.

Peraturan Pemerintah Nomor 80 Tahun 2019 tentang Commerce Via Electronic System (PMSE). Pierre, J., \& Peters, B. G. (2005). Governing Complexs Societis: Trajectories and Scenarios. New York: Palgrive Macmillan.

Sembiring, R. A., \& Subekti, T. (2020). Upaya Dinas Koperasi, Usaha Mikro, dan Perdagangan (DISKUMDAG) Kota Batu dalam Memberdayakan Pelaku Usaha Kecil Menengah (UKM) Produk Tujuan Eksport. Journal of Governance Innovation, 2(2), 83-92.

Sudarmo. (2011). Isu-Isu Administrasi Publik dalam Perspektif Governnace. Solo: Smartmedia dan MAP UNS.

Sumarto, Hetifah. S. (2009). Inovasi, Partisipasi, dan Good Governance. Jakarta: Yayasan Obor Indonesia.

Suyanto, B., \& Sutinah. (2005). Bagong Suyanto dan Sutinah (ed). 2005. Metode Penelitian Sosial: Berbagai Alternatif Pendekatan. Kencana: Prenadamedia Group. Jakarta: Kencana Prenada Media Group.

UN ORG. (2012). UN System Task Team On The Post-2015 UN Development Agenda: Governance and Development (page 3), https://www.un.org/millenniumgoals/pdf/Think\%20Pieces/7_governance.pdf.

Yulianto. (2020). Luki Budiarti Sang Arsitek Arjuna Flora, https://tabloidsinartani.com/detail/indeks/agri-profil/11847-Luki-Budiarti-sangArsitek-Arjuna-Flora. 